\title{
EFFECT OF CLIMATE ON YAM TUBERIZATION IN THE GUINEA SAVANNA ECOLOGICAL ZONE OF NIGERIA: THE CASE STUDY OF KWARA STATE \\ SADAUKI, A. A. ${ }^{1}$ and ${ }^{*}$ OLANREWAJU R.M. ${ }^{2}$

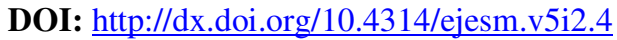

Received 12th December 2011; accepted 7th March 2012

\begin{abstract}
The response of yam tuber development to its micro-climate was monitored at the National Centre for Agricultural Mechanization (NCAM) for two yam growing seasons. The micro climate data measured include air temperature, rainfall, number of rain days, relative humidity, soil temperature at intervals of $5 \mathrm{~cm}, 20 \mathrm{~cm}, 30 \mathrm{~cm}$ and $40 \mathrm{~cm}$ and soil moisture with depths at $0-15 \mathrm{~cm}$, $15-30 \mathrm{~cm}$ and $30-45 \mathrm{~cm}$. Measurement of yam tuber circumference and length were taken on monthly basis from the period of tuber initiation (34 WAP) to period of tuber maturity (50 WAP) using thread and measuring tape. Monthly means of weather elements from research plot was calculated, grouped and summarized using descriptive statistics of mean and percentages. Dependency of yam tuber development on meteorological factors was examined through statistical analysis of correlation and regression. Based on this, the period of tuber development in Kwara State was identified and categorized. The growth in yam tuber responds positively more to rainfall frequency than rainfall amount. Again soil temperature at $5 \mathrm{~cm}$ depth was identified to be more critical for efficient yam tuberization. Farmers in the study area are advised to improve on the materials used for mulching to increase yam yield.
\end{abstract}

\section{Introduction}

Yam tuber is the storage organ of yam plant and constitutes the most significant economic part used majorly for human consumption in Nigeria. Dioscorea rotundata (white yam) and $D$. alata (water yam) are important staple food and sources of carbohydrate to Nigerian's diet.

Although Nigeria is witnessing a sporadic rise in yam production (CBN, 2008) yet not all yam producing area in Nigeria can boast of the upward trend in yam production, example of such is Kwara State (Kwara State Agricultural Project (KADP) field survey 2010). The production trend of yam in Kwara State has not been steady. Yield and area devoted to yam production fluctuates together. The implication is that more land area is being put under yam cultivation to increase production yearly For instance,the hectares of land put into cultivation in 1995 was 26.10 (000) when production was 294.30 (000 tons) and yield stood at 11.20 (000 tons). Ten years later in 2004 , to raise yam production level to 480.70 (000 tons) and yield to 12.20 (000 tons), 38.60 (000) hectares of land was cultivated while production level increased to 480.70 (000 tons).
Such spatial shift in yam cropping pattern may result in mismatch of environment and yam cropping which will result in crop failure.

To avoid this, there is need for an improved understanding of yam growing environment to enhance its high steady production in Kwara State. Climate has been recognized as the major components of the environment that control crop production of the rain fed tropical agriculture (Oguntoyinbo, 1981; Adefolalu, 1999, Ayoade, 2004, Adefolalu, 2005). Bello (2010) emphasized the need to monitor the effect of climatic factors on agriculture from the field. Such exercise enables us to see the reality of climate effects on agriculture. Thus, this study examined the response of yam tuber development to its micro climate in the guinea savanna ecological zone of kwara State, Nigeria.

\section{Study Location}

The experimental farm plot was sited at the National Centre for Agricultural Mechanization (NCAM). The location is Kilometre 12 IlorinIdofian road at latitude $830^{\prime}$ North of the equator and longitude 4 35East of the Greenwich meridian.

${ }^{1}$ Department of Geography, Federal University of 
Olaniran (1986) described the climate of the area as guinea savanna in his climatic classification scheme. Mean annual rainfall varies and the regime shows a south-north gradient. Temperature is high throughout the year. The study area is characterized by ferruginous tropical soil and the vegetation belongs to the category of guinea savanna community.

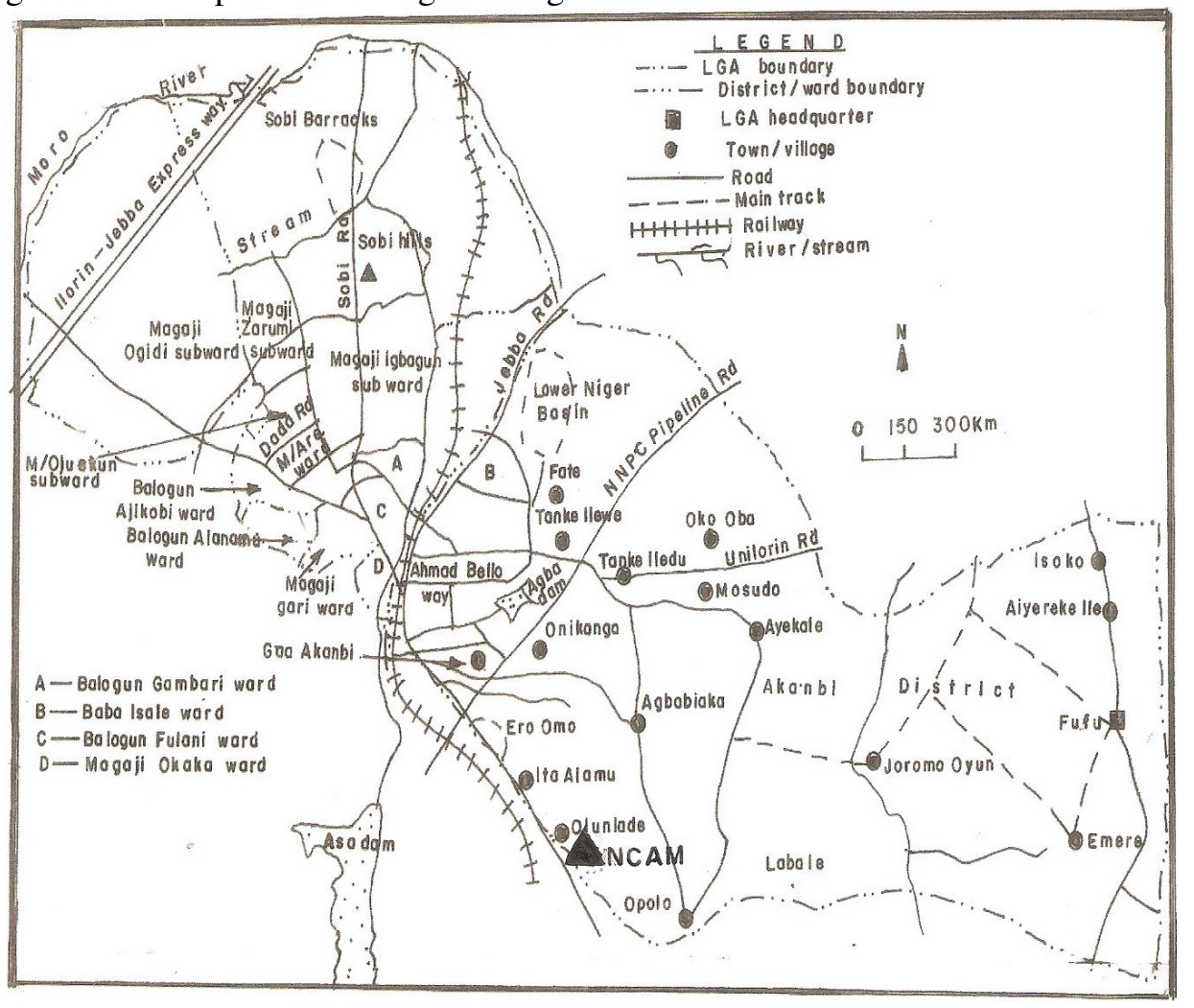

Figure 1 Map of Ilorin South LGA Showing the Location of NCAM

\section{Methodology \\ Experimental Design}

The study of the fundamentals of plantclimate relationship as advocated by Olaniran (1981) was adopted. The research farm ran for two consecutive yam cropping seasons of 2005/2006 and 2006/2007. Each cropping season spanned between October to September of the following year. The cultivar of interest was $D$. rotundata. This is because it is the most favoured yam species in West Africa (Okoro, 1990) and especially in Kwara State, Nigeria (Olanrewaju, 2009).

Farm land was cleared and left for about twelve days to ferment. Measurements and demarcation of plot followed after which one hundred heaps (yam seed beds) were prepared manually using big hoe.
A whole yam seed was planted on each heap and mulched immediately. This is because study showed that whole yam seeds yield better than setts (Onwueme, 1984) and mulching of yam bed also enhanced yam yield in the study area (Olanrewaju, 2009). Installation of weather instruments for measuring weather variables was done. The micro climatic data measured include air temperature, rainfall amount, number of rain days, relative humidity and all these form the aerial micro climatic data. The sub-aerial micro data collected were soil temperature at intervals of $5 \mathrm{~cm}, 10 \mathrm{~cm}$, $20 \mathrm{~cm}, 30 \mathrm{~cm}$ and $40 \mathrm{~cm}$, soil moisture with depths at $0-15 \mathrm{~cm}, 15-30 \mathrm{~cm}$ and $30-45 \mathrm{~cm}$. These depths were used because yam tubers 
and roots grow within these soil depths. There was no application of any farm input because the study is ethno scientific.

\section{Measurements and Data Collection}

Weather variables were recorded on daily basis, collated weekly and summarized monthly. Length and circumference of yam tubers were measured on monthly basis from the period of tuber initiation at 34 weeks after planting (WAP) to period of tuber maturity (50 WAP). This was done by careful uprooting of five yam plant stands randomly every month. The length and circumference of tubers were then measured using thread and measuring tape.

\section{Data Analysis}

Monthly means of both weather variables and yam development (length and circumference) were calculated, grouped and summarized. Data was subjected to correlation and regression analyses to determine dependency of yam tuber development on meteorological factors.

\section{Results and Discussion}

Figure 1 below reflects the relationship between land devoted to yam cropping and yield between 1965 and 2008. Both yam yield and the number of hectares put into cultivation yearly fluctuated together.

The pattern of yam tuber development from the period of tuber initiation at 34 WAP through 50 WAP when matured tubers were harvested is shown in figure 3 .

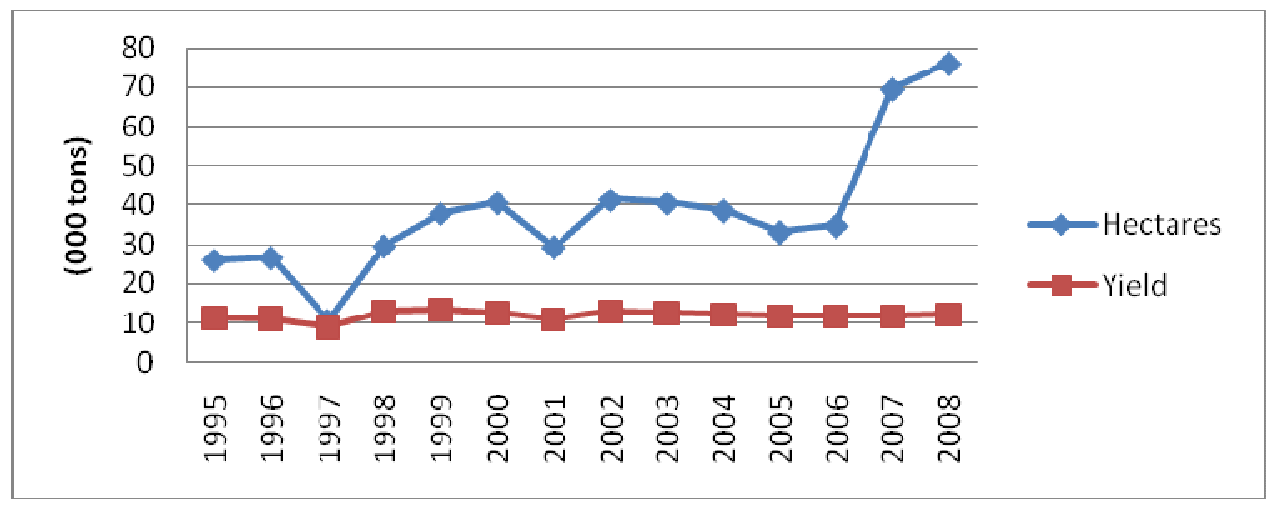

Figure 2 Land Devoted to Yam Cropping and Yield

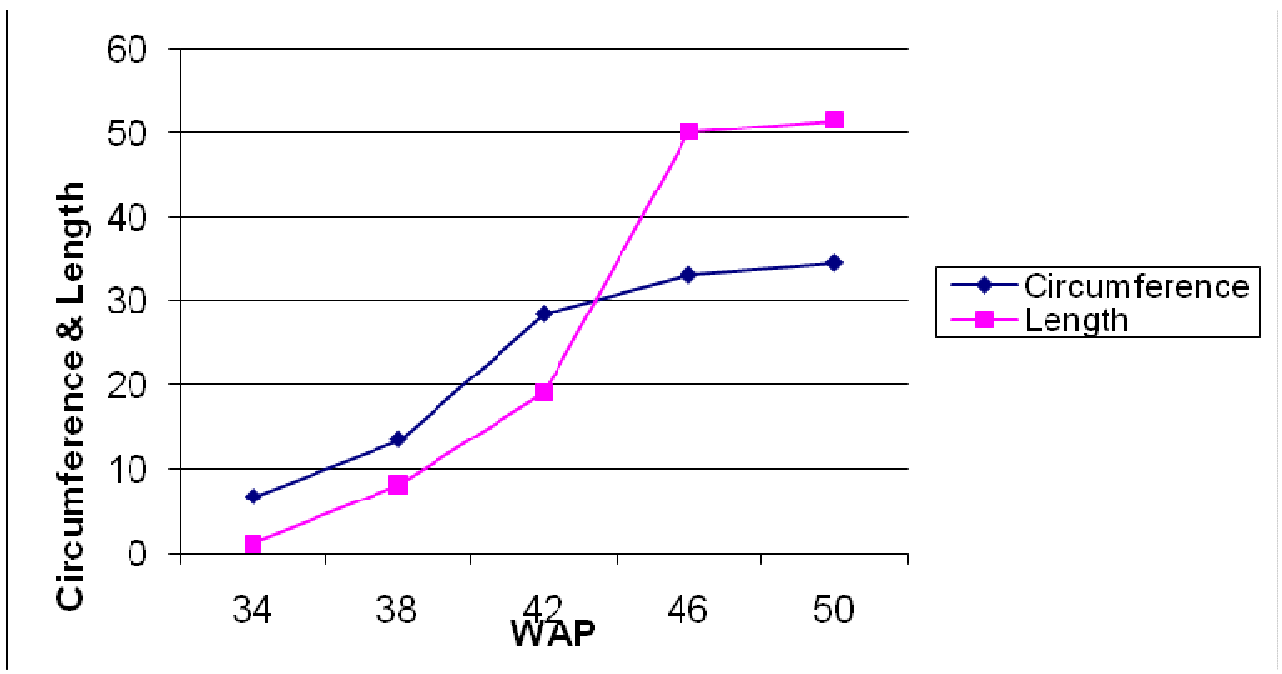

Figure 3 The Circumference and Length of Yam Tuber During its Development 
Rapid enlargement and elongation of yam tubers occurred after initiation at 34 WAP through 46 WAP. Thereafter the formation of yam tuber slowed down drastically. For instance at 50 WAP tuber circumference increased only by $1.4 \mathrm{~cm}$ and was just $1.3 \mathrm{~cm}$ longer than what it was at 46 WAP. The implication is that yam tuber formation ceased at $50 \mathrm{WAP}$. This finding is in broad agreement with Njoku et al (1984) who put the period of tuber formation in $D$. rotundata at about 120 days (which is equivalent to four months) after initiation.

When the rate of tuber enlargement was compared with that of tuber elongation certain pattern of tuber formation was observed (Fig 2). The rate at which yam tuber elongated was slower than the rate at which it enlarged between 34WAP and 42WAP. However, at about 44 WAP equilibrium was reached between the two dimensions of yam tuber growth. Thereafter, there was a sporadic elongation of yam tuber above tuber enlargement. This pattern of tuber development was maintained through 50 WAP when tubers were harvested.

Based on these findings, the period of yam tuber development in the study could be categorized thus;

$30-34$ WAP period of tuber growth initiation $35-42$ WAP period of slow tuber development 43 -46WAP period of rapid tuber development 47 -50WAP period of tuber growth cessation.

Pattern of Aerial and Sub-Aerial Microclimate of Yam Plant during Tuber Formation

\section{Pattern of Aerial Micro Climate}

The pattern of the mean weekly rainfall, number of rain days, relative humidity, evaporation, minimum and maximum temperatures during the period of $D$. rotundata tuberization in the study area is displayed in table 1 below.

Table 1 Pattern of aerial micro climate during yam tuberization

\begin{tabular}{lllllll}
\hline WAP & $\begin{array}{l}\text { Rainfall } \\
(\mathrm{mm})\end{array}$ & $\begin{array}{l}\text { No. of } \\
\text { rain day }\end{array}$ & R.H $(\%)$ & $\begin{array}{l}\text { Evaporation } \\
(\mathrm{mm})\end{array}$ & $\begin{array}{l}\text { Min Temp. } \\
\left({ }^{0} \mathrm{C}\right)\end{array}$ & $\begin{array}{c}\text { Max. Temp } \\
\left({ }^{0} \mathrm{C}\right)\end{array}$ \\
\hline 34 & 148.2 & 9 & 59.40 & 3 & 25.0 & 34.0 \\
38 & 220.2 & 14 & 60.0 & 2.9 & 22.40 & 30.42 \\
42 & 126.6 & 11 & 76.0 & 2.5 & 22.30 & 30.0 \\
46 & 78.0 & 12 & 77.81 & 1.80 & 22.31 & 29.32 \\
50 & 340.0 & 16 & 80.0 & 1.90 & 22.30 & 30.13 \\
\hline
\end{tabular}

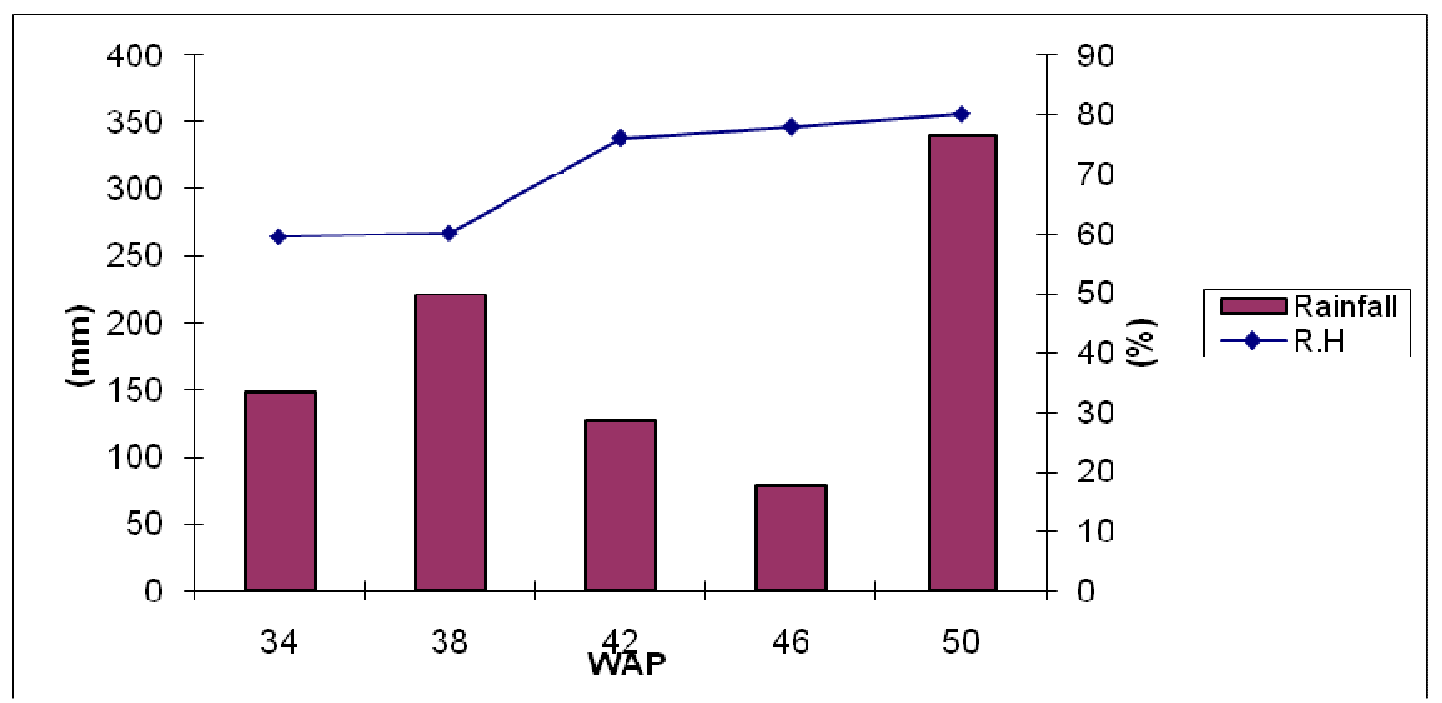

Figure 4 Pattern of Rainfall Amount and Relative Humidity during Yam Tuberization 
Rainfall amount fluctuated and revealed a double maxima pattern at $38 \mathrm{WAP}$ and at 50 WAP respectively. These two peaks were separated by a period of short dry spell experienced between $42 \mathrm{WAP}$ and 46WAP (August break). Rainfall distribution also fluctuated between nine days at 34 WAP and 16 days at 50 WAP. Relative humidity fluctuated with rainfall amount to a certain extent. For instance, increase in rainfall amount resulted in increase in relative humidity at 34WAP, 38WAP and 50WAP respectively. However, this pattern was disrupted during 42WAP and 46WAP when relative humidity increased with a decline in rainfall amount, Lowest value of evaporation was recorded between $46 \mathrm{WAP}$ and $50 \mathrm{WAP}$. This marks the period when the sky isusually overcast by a low cumulus cloud thus blocking the earth surface from direct impact of solar radiation. This blockage lowers evaporation rate during this period. Air temperature ranged between $29.32^{\circ} \mathrm{C}$ recorded at 46 WAP and $34^{\circ} \mathrm{C}$ observed at 34 WAP.

\section{Pattern of Sub aerial Microclimate}

Table 2 showed the level of variation in mean soil temperature at various depths during the period of yam tuberization. Generally soil temperature declined with depth. It was highest at $5 \mathrm{~cm}$ depth and least at $40 \mathrm{~cm}$ depth but the degree of variation became less pronounced with depth (Figure 5). For instance at 34 WAP the difference in soil temperature between $5 \mathrm{~cm}$ and $10 \mathrm{~cm}$ depth was $3.08^{\circ} \mathrm{C}$ but reduced to about $1.16^{\circ} \mathrm{C}$ between $30 \mathrm{~cm}$ and $40 \mathrm{~cm}$ soil depth. This pattern was maintained through 50 WAP.

Table 2 Soil Temperature $\left({ }^{0} \mathrm{C}\right)$ at various depths during Tuber Development

\begin{tabular}{llllll}
\hline WAP & $5 \mathrm{~cm}$ & $10 \mathrm{~cm}$ & $20 \mathrm{~cm}$ & $30 \mathrm{~cm}$ & $40 \mathrm{~cm}$ \\
\hline 34 & 35.36 & 30.28 & 29.42 & 27.35 & 26.19 \\
38 & 32.12 & 29.42 & 28.37 & 26.66 & 25.17 \\
42 & 32.10 & 29.61 & 28.0 & 27.46 & 25.05 \\
46 & 30.0 & 28.27 & 28.0 & 26.0 & 25.65 \\
50 & 33.50 & 31.54 & 31.0 & 28.27 & 27.0 \\
\hline
\end{tabular}

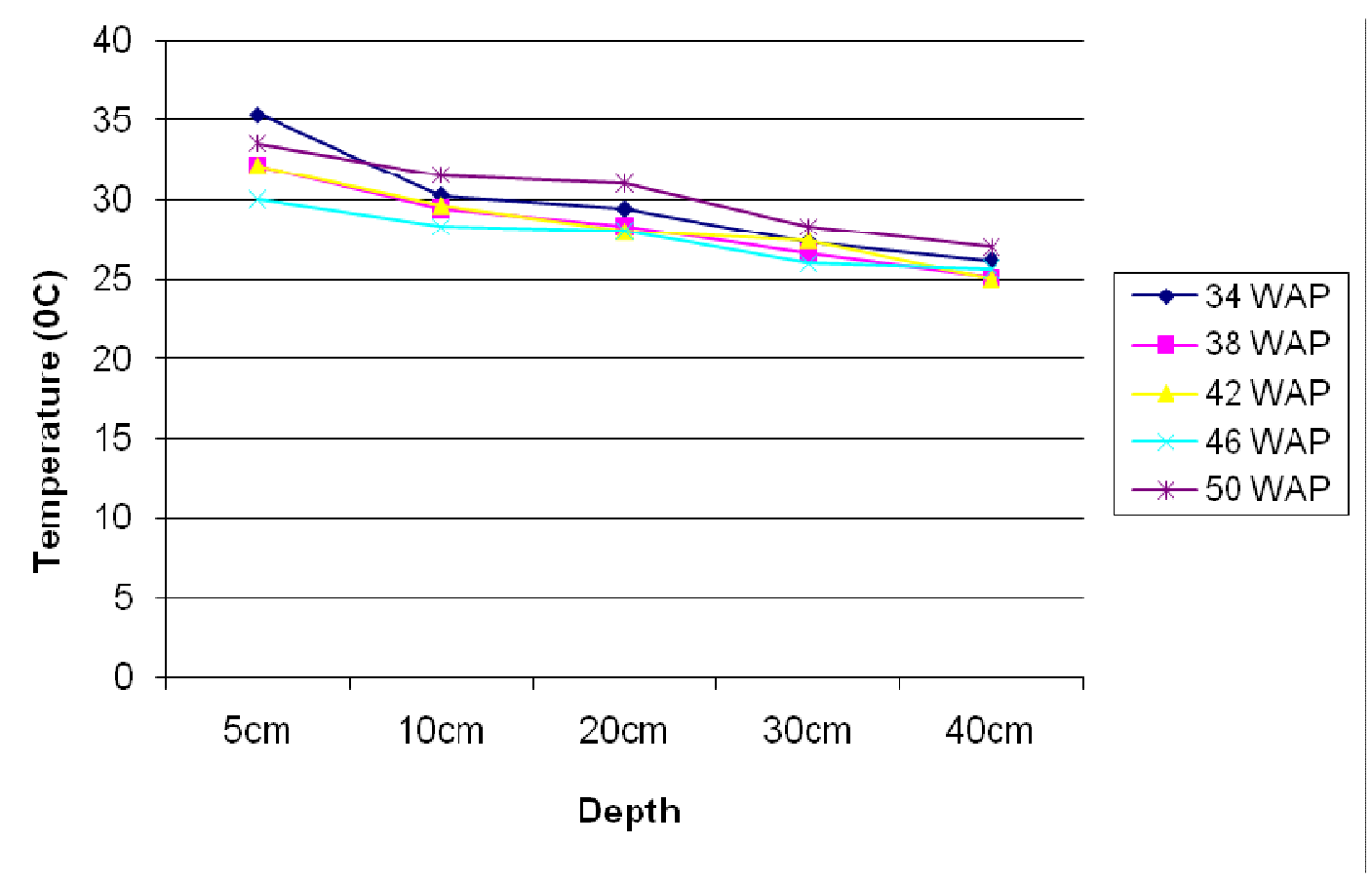

Figure 5 Soil Temperature at various depths during yam tuberization 
Uvertime, the range in soll temperature between 34 WAP and 50WAP within each soil depth showed that soil temperature was highest at $5 \mathrm{~cm}$ depth during 34 WAP. However at the soil depth of $10 \mathrm{~cm}$ to $40 \mathrm{~cm}$ highest soil temperature was recorded by $50 \mathrm{WAP}$ and least at 46 WAP respectively.

The pattern of soil moisture at various depths during yam tuberization is displayed in table 3 . Generally soil moisture increase with depth, least at soil depth interval of $0-15 \mathrm{~cm}$ depth and greatest at an interval of between $30 \mathrm{~cm}$ and $45 \mathrm{~cm}$. Variation in soil moisture also faded out w1th depth. So1l depth intervals of 15-3Ucm and $30-45 \mathrm{~cm}$ observed almost similar \% of soil moisture during 42 WAP and 46 WAP (Figure $6)$. As a matter of fact, a slight decline from $24.45 \%$ to $24 \%$ occurred at 46 WAP. Overtime, soil moisture varied. The period of 34 WAP after planting observed the least values while the highest \% was recorded at 50 WAP at all depths. It is important to point out that this kind of variation has been noted in soil temperature. The implication is that an increase in soil temperature brings about a decline in soil moisture.

Table 3 Soil Moisture at various Soil depths (\%) during tuber Development

\begin{tabular}{llll}
\hline WAP & $0-15 \mathrm{~cm}$ & $15-30 \mathrm{~cm}$ & $30-45 \mathrm{~cm}$ \\
\hline 34 & 16.12 & 18.53 & 19.17 \\
38 & 17.70 & 20.17 & 21.54 \\
42 & 21.0 & 24.0 & 21.55 \\
46 & 20.25 & 24.45 & 24.0 \\
50 & 21.55 & 24.43 & 25.06 \\
\hline
\end{tabular}

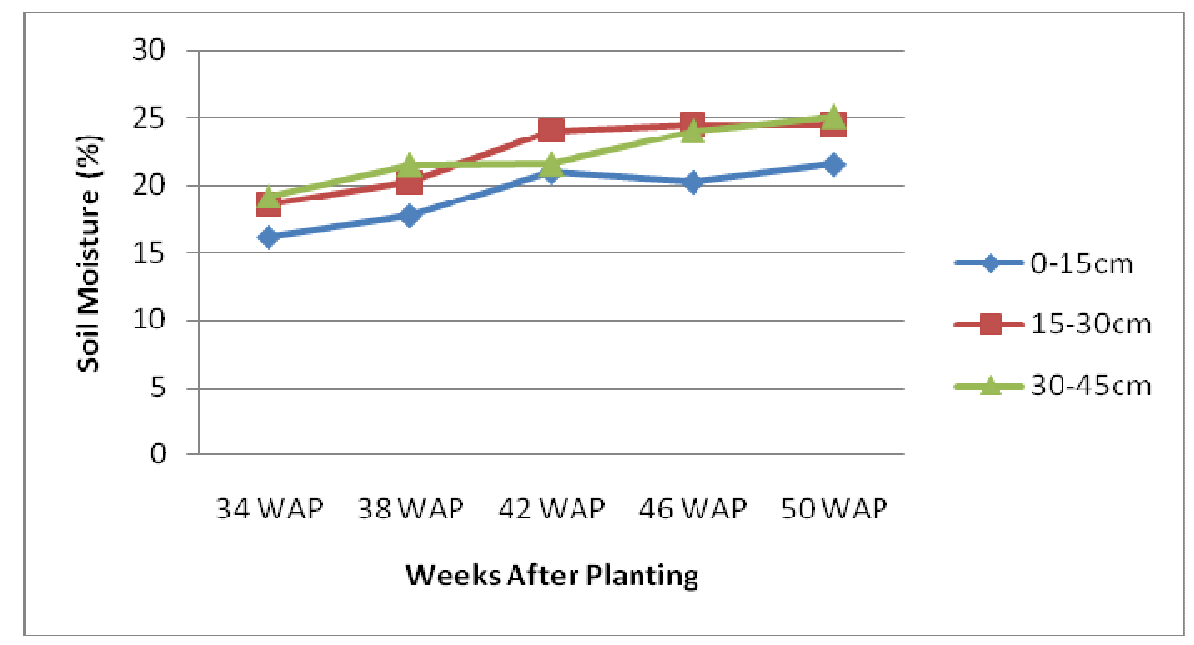

Figure 6 Soil Moisture at various depths during yam tuberization

\section{A Comparison of Yam Tuber Development and Climate \\ Aerial Micro Climate}

It appeared tuber formation is favoured by low rainfall amount that is well spread. Yam tuber developed with greatest vigour between 42 WAP and 46 WAP. This period was characterized by low amount of rainfall that was well distributed. This finding has further corroborated the work of Bello (1987) that the amount of rainfall is not as important as its spread for yam to perform well in the field. After rain has been established it must be evenly distributed for proper growth and enlargement of yam tuber. This period recorded high relative humidity with low evaporation rate. Air temperature ranged between $29^{\circ} \mathrm{C}$ and $30^{\circ} \mathrm{C}$. This is also in 
agreement with Mozie and Okoro (1990), Indira (1998) and Okuewu (2002) that yam requires a temperature range of $25-30^{\circ} \mathrm{C}$ for its optimum performance. Yam grows better under warm sunny condition.

\section{Sub-Aerial Microclimate}

Optimum soil temperature for the growth of yam according to Onwueme (1977) ranged between $25-35^{0} \mathrm{C}$. Soil temperature shortly before rapid tuber formation (42-46 WAP) ranged between $25^{\circ} \mathrm{C}-32^{\circ} \mathrm{C}$ thus in agreement with the recommended values. It appeared too much soil moisture does not favour tuber development most especially elongation. Tuber elongation was most rapid between 42 WAP and 46 WAP with a slight decline in soil moisture.

The strength of the relationships between yam tuber development and both aerial and sub aerial micro climate is discussed in this section. Table 4 below displayed the level of correlation between tuber enlargement and elongation and the elements of aerial climate of yam plant.

Table 4 Correlation between yam tuber Development and Aerial Micro climate

\begin{tabular}{lll}
\hline Climatic element & Circumference & Length \\
\hline Rainfall $(\mathrm{mm})$ & 0.13 & 0.21 \\
No. of Rain days & 0.52 & 0.58 \\
Relative Humidity $(\%)$ & $0.98^{* *}$ & $0.88^{* *}$ \\
Evaporation $(\mathrm{mm})$ & $-0.93^{*}$ & $-0.99^{* *}$ \\
Minimum Temp $\left({ }^{\circ} \mathrm{C}\right)$ & -0.76 & -0.61 \\
Maximum Temp $\left({ }^{0} \mathrm{C}\right)$ & -0.82 & -0.69 \\
\hline * Correlation significant at 0.05 levels & $* *$ Correlation significant at 0.01 levels
\end{tabular}

The result of correlation confirmed the assertion made earlier that rainfall amount is not as important as its spread. Positive relationship that is stronger exists between tuber formation and number of rain days than between rainfall and tuber development. However relative humidity exhibits the strongest positive relationship with yam tuber development. Increase in air temperature and evaporation reduce tuber development in the field. A strongest negative relationship significant at 0.05 levels and 0.01 level exist between tuber circumference, tuber elongation and evaporation.

Soil temperature and soil moisture at varying depths described the sub aerial climate of crop plant. Table 5 shows the result of correlation between yam tuber enlargement, elongation and soil temperature at the depths of $5 \mathrm{~cm}, 10 \mathrm{~cm}, 20 \mathrm{~cm}, \quad 30 \mathrm{~cm}$ and $40 \mathrm{~cm}$ respectively.
Soil temperature at $5 \mathrm{~cm}$ depth is the most critical for both tuber enlargement and elongation. The strongest negative relationship between the two variables of growth and soil temperature occurred at $5 \mathrm{~cm}$ depth. At $10 \mathrm{~cm}$ depth the negative relationship has weakened and between $20 \mathrm{~cm}$ through $40 \mathrm{~cm}$ depths mild positive relationship which grew in strength with depth was established. The implication is that between the soil depths of $5 \mathrm{~cm}$ to $10 \mathrm{~cm}$ increase in soil temperature hampered tuber development. However tuberization is enhanced between the soil depths of $20 \mathrm{~cm}$ through $40 \mathrm{~cm}$ with increase in soil temperature.

The relationship between soil moisture and yam tuber formation is reflected in table 6 below. Tuber enlargement and elongation established positive relationship with soil moisture at all depths considered. However it is important to note the variation in the strength of these relationships. The positive relationship 
between tuber enlargement and soil moisture is significant at 0.01 levels of confidence between the soil depths at $0-15 \mathrm{~cm}$ through $15-30 \mathrm{~cm}$ but significant at 0.05 levels between $30-45 \mathrm{~cm}$. The implication is that the amount of soil moisture required for tuber enlargement diminishes with depth.

The positive relationship established between yam tuber elongation and soil moisture is not as strong as with that of tuber enlargement. The implication is that too much soil moisture is not necessary for yam tuber to grow in length.

\section{Summary and Conclusion}

The study examined the responses of yam tuber development to its micro climate using the fundamentals of plant-climate relationship. An experimental farm plot was set up at
NCAM where both the aerial and sub-aerial climatic environment of yam tuber was monitored for two yam growing seasons.

The period of rapid yam tuberization occurred between 34 WAP through 46WAP. Air temperature range of between $29^{\circ} \mathrm{C}-30^{\circ} \mathrm{C}$ and soil temperature of between $25^{\circ} \mathrm{C}-32^{\circ} \mathrm{C}$ have been identified for optimum yam tuberization in the guinea savanna ecological zone of Kwara State. Again tuber formation is favoured by rainfall that is well spread. Soil temperature at $5 \mathrm{~cm}$ depth is most critical for tuber development. Soil moisture at all depths shows a positive relationship with tuber formation.

Farmers in the study area are encouraged to improve on the materials used in mulching yam beds. They could adopt the use of plastic which cannot decay with time.

Table 5 Result of correlation between yam tuber Development and soil Temperature at varying depths

\begin{tabular}{llllll}
\hline Yam tuber & $5 \mathrm{~cm}$ & $10 \mathrm{~cm}$ & $20 \mathrm{~cm}$ & $30 \mathrm{~cm}$ & $40 \mathrm{~cm}$ \\
\hline Circumference $(\mathrm{cm})$ & -0.60 & -0.12 & 0.01 & 0.01 & 0.19 \\
& & & & & \\
Length $(\mathrm{cm})$ & -0.52 & -0.03 & 0.02 & 0.03 & 0.44 \\
\hline
\end{tabular}

Table 6 Results of Correlation between yam tuber development and soil moisture at varying depths

\begin{tabular}{llll}
\hline Yam tuber & $\mathbf{0 - 1 5} \mathbf{c m}$ & $\mathbf{1 5 - 3 0 c m}$ & $\mathbf{3 0 - 4 5} \mathbf{c m}$ \\
\hline Enlargement $(\mathrm{cm})$ & $0.96^{* *}$ & $0.99^{* *}$ & $0.89^{*}$ \\
& & & \\
Elongation $(\mathrm{cm})$ & 0.80 & 0.86 & $0.95^{*}$ \\
\hline * Significant at 0.05 level & ** Significant at 0.01 level &
\end{tabular}

\section{References}

Adefolalu, D.O. (1999), Intitutional Framework - Suggestion: First National Summit on Ecology and Environment. The presidency. Abuja. Pp $2-5$.

Adefolalu, D.O. (2005), Climate ChangeGlobal Warming local warning in Nigeria. NASS Senate $3^{\text {rd }}$ Annual Conference Abuja. P. 29.

Ayoade, J.O. (2004), Introduction to Climatology for the Tropics. Spectrum Books Limited, Ibadan. P. 258.
Bello, N.J. (1987), An Assessment of Water Supply for Agriculture in the Niger River Basin Development Authority Area, Agric and Forest Meteorology, (40), 109-121.

Bello, N.J. (2010): Climate Change: Implications for food production and security in Nigeria. Pp. 1-14. A special Book on climate change, NMets 2010.

Central Bank of Nigeria Annual Report and statement of Accounts for the year ended $31^{\text {st }}$ December 2008. 
Indira, J.E. (1998), Screening for Abiotic stress resistance in root and tuber crops. IITA Research Guide; 1:68. Pp. 1-46.

Kwara Agricultural Development Project Report, 2010.

Mozie, O and Okoro (1990), Farmers' Bookshelf: An Information System of Tropical Crops in Hawaii. Department of Tropical Plant and Soil Sciences, University of Hawaii at Manoa.

Okuewu, B. (2002), Agriculture: The Need for Marketing Information. The Monitor, Thursday May $2^{\text {nd }}$. Pp. B3-B5.

Olaniran, O.J. (1981), Research in Agroclimatology in Nigeria. J. Agric Res. Pp. 15-29.
Olaniran, O.J. (1986), 'On the classification of Tropical Climates for the Study of Regional Climatology : Nigeria as a Case Study, Geografiska Annaler 68A, 4, 233-244.

Olanrewaju, R.M. (2009), Climate and the Growth Cycle of Yam Plant in the Guinea Savanna Ecological Zone of Kwara State, Nigeria. J. of Met. And Cli. Sci. 7: 43-48.

Onwueme, I.C. (1977), Field Comparison of West African Planting and Harvesting Practices in Yam Pre-sprouting Dry Season Planting and Double Harvesting. J. of Agric Science, 88:311-318.

Onwueme, I.C. (1984): Yam: in Goldsworthy and Fisher, N.M (eds): The Physiology of Tropical Field Crops. John Wiley and Sons Ltd. London U.K. 